\title{
INTERNALISASI NILAI-NILAI AKHLAQUL KARIMAH SISWA PADA PEMBELAJARAN AKIDAH AKHLAQ DI MADRASAH IBTIDAIYAH KECAMATAN WINDUSARI KABUPATEN MAGELANG
}

\author{
Sigit Tri Utomo dan Ahmad Sa'i \\ STAINU Temanggung dan Kemenag Kabupaten Magelang, \\ Jawa Tengah, Indonesia \\ Sigit.triutomo@yahoo.com
}

\begin{abstract}
This research is a qualitative descriptive reserach. The datawere obtained throughobservation, interviews and documentation. The data analysis used datareduction, to describe theInternalization of Akblaqul Karimah Values in this case the students of class $V$ atLearning Aqeedah Akblaq in Government Elementary School District ofW indusariMagelang district case study in MI Al-Islam Balesari, Al-Islam Kembangkuning MIand MI Nurul Huda Candisari. The results showed that: 1) Learning Aqeedah Akblaq includesseveral stages such as: (a) the stages of recognition and understanding of the materialtanght, (b) the acceptance stage by wanting process of learning to feel related to theenvironmental context as in activities religious, exemplary, habituation motivation, (c) the stages of integration, namely a student started to enter a value intoa whole system of values
\end{abstract}


inprofess.2) Learning Aqeedah Akhlaq include: transinternal strategy, ie a strategy that involves teachers and students inactive communication, whether verbal, physical or mental. There is also acontributing factor, such as the addition of clock subjects in religious activities withtheir own material, then the school is located in a rural environment for learningstrategic, religious activities, discipline, school environmental situation, exemplaryand habituation collectively the same has led to the internalization of good moralvalues. The inhibiting factors include the level of student understanding of Islam isdifferent.

Keywords: Internalizing values, Akblakul Karimah, Learning Aqeedah Akhlaq.

\begin{abstract}
Abstrak
Penelitian ini merupakan penelitian kualitatif deskriptif.Datadatadiperoleh melalui observasi, wawancara, dan dokumentasi. Analisis data menggunakan reduksi data, untuk mendeskripsikan Internalisasi Nilai-Nilai Akblaqul Karimahsiswa Kelas V pada Pembelajaran Akidah Akhlaq di Madrasah Ibtidaiyah Kecamatan Windusari kabupaten Magelang studi kasus di MI Al-Islam Balesari, MI Al-Islam Kembangkuning, dan MI Nurul Huda Candisari. Hasil penelitian menunjukkan babwa: 1) Pembelajaran Akidah Akblaq meliputi beberapa tahapan seperti: (a) tahapan pengenalan dan pemahaman terhadap materi yang diajarkan, (b) tahap penerimaan dengan menginginkan proses belajar merasakan berkaitan konteks lingkungan seperti dalam kegiataan keagamaan, keteladanan, pembiasaan seta motivasi, (c) tahapan pengintegrasian, yaitu seorang pelajar mulai memasukkan nilai ke dalam keseluruban sistem nilai yang di anutnya. 2) Pembelajaran Akidab Akblaq meliputi: strategi transinternal, yaitu strategi yang melibatkan guru dan siswa dalam komunikasi yang aktif, baik verbal, fisik maupun batin. Selain itu juga terdapat faktor pendukung, seperti adanya penambahan jam mata pelajaran pada kegiatan keagamaan dengan materi tersendiri, kemudian sekolah berada di lingkungan pedesaan yang strategis untuk proses belajar, kegiatan-kegiatan keagamaan, tata tertib, situasi lingkungan sekolah, keteladanan dan pembiasaan secara bersama-sama telah mengarah pada internalisasi nilai-nilai akblaqul karimah. Adapun faktorpenghambatnya meliputi tingkat pemahaman siswa terhadap ajaran Islam yang berbeda.
\end{abstract}

Kata kunci: Internalisasi nilai-nilai, Akblakul Karimah, Pembelajaran Aqidah Akhlaq. 


\section{A. Pendahuluan}

Pendidikan adalah upaya mencerdaskan bangsa, dengan pendidikan diharapkan adanya peradaban manusia yang mempunyai harkat dan martabat yang menjunjung tinggi nilainiIai budi pekerti yang menjadi cerminan sifat manusiawi. Terutama pada pendidikan dasar sangat memerlukan perhatian yang serius. Akan tetapi, seiring berjalannya era globalisasi sifat manusia cenderung pada arah moral yang terdegradasi. Hal ini terlihat dengan banyaknya kasus yang mencederai negeri ini sehingga menjadi catatan merah yang harus dibenahi oleh berbagai pihak tak terkecuali para praktisi dan para akademisi, seperti adanya kasus perkosaan, pencurian, kenakalan para remaja gaya dengan hidup yang berpola westernisasi.

Hal ini sangat bertolak belakang pada jati diri bangsa yang sangat menghargai dan menghormati manusia sebagaipemimpin di muka bumi. Sungguh ironis, pendidikan yang sejatinya membangun pribadi yang holistik, dimana setiap individu dapat menemukan identitas diri, makna, dan tujuan hidupnya melalui hubungan dengan alam, lingkungan dan nilai-nilai spritualitas (ketuhanan) atau membelajarkan aspek kognitif, afektif, dan psikomotorik, realitasnya hanya aspek kognitif saja yang membuat anak teralisienasi dari lingkungannya. ${ }^{1}$ Sehingga dalam berproses pendidikan menurut penulis ketiga aspek tersebut sebaiknya di integrasikan menjadi satu kesatuan agar tujuan mencetak manusia sebagai khalifah fil ardl dapat termanifestasi.

Dewasa ini problem pelajar pada peserta didik tingkat dasar atau madrasah adalah perilaku tercela yang sering diindikasikan pada suka merokok, menononton film pornografi, dan perilaku yang menyimpang lainnya yang tidak sesuai dengan norma masyarakat. Terlebih para remaja terutama pelajar adalah mudah terprovokasi yang tidak terkendali sehingga berujung

${ }^{1}$ Agus Zaenul Fitri, Pendidikan Karakter Berbasis Nilai dan Etika di Sekolah (Yogyakarta: Ar-Ruzz Media, 2012), hlm. 10. 
pada tawuran antar pelajar, seperti yang diberikan pada media cetak dan media massa. Di kota-kota besar pelajar terlibat dalam penyalahgunaan obat-obatan terlarang, seperti narkoba dengan berbagai jenisnya. Bahkan, stigma para pelajar saat ini diperparah oleh berbagai perilaku penyimpangan sosial yang mereka lakukan dalam bentuk pergaulan bebas seperti free sex, aborsi, homoseksual, lesbian, dan sebagainya. ${ }^{2}$ Kebiasaan ini sungguh menjadi hal yang sangat ironi jika dikaitkan dengan jati diri bangsa yang mengedepankan moral dalam kehidupan.

Dari uraian diatas, penulis mencermati pendidikan esensinya mampu memberikan kontribusi pada pembentukan jati diri generasi bangsa. Dalam konteks kehidupan yang demikian, pendidikan Islam dalam hal ini pada proses pembelajaran akidah akhlaq diharapkan lebih mampu dan memberikan solusi solutif yang sekaligus menjadi bahan evaluasi dan koreksi diri pada implementasi yang selama ini dilakukan, terutama pada siswa di Madrasah Ibtidaiyah.

Karena persoalan pendidikan yang dihadapi oleh bangsa Indonesia saat ini bukan terkaitdengan persoalan kualitas sumber daya manusianya, namun lebih tepat pada sistem dan lingkungan pendidikan yang tidak mampu menunjang bagi perkembangan manusia secara maksimal. ${ }^{3}$ Secara paradigmatik, pembelajaran akidah akhlaq di madrasah perlu diorientasikan pada ajaran Islam yang rabmatan lil 'alamin. Islam yang memberi manfaat kepada siswa. Pendekatan pembelajaran akidah akhlaq di madrasah hendaknya dilakukan secara kontekstual, yaitu dikaitkan dengan konteks dan kebutuhan siswa yang dapat membantu mengatasi problem-problem nyata yang dihadapi, pembelajaran yang mampu memberi kesempatan kepada siswa untuk memahami dan mendiskusikan materi pelajaran. Bahkan, siswa difasilitasi untuk

${ }^{2}$ Agus Zaenul Fitri, Pendidikan Karakter Berbasis Nilai.., hlm. 10.

${ }^{3}$ Zuhari, dkk. Metodik Khusus Pendidikan Agama; Dilengkapi dengan Sistem Modul dan Permaianan Simulasi (Surabaya: Biro Ilmiah Fakultas Tarbiyah IAIN Sunan Ampel Surabaya dan Usaha Offset Printing, 1983), hlm. 27. 
melakukan dan mengamalkan apa yang telah mereka pelajari dalam kehidupan sehari-hari. ${ }^{4}$ Karena dengan pengamalan terhadap materi pelajaran yang diserap peserta didik jelas akan mewujudkan masyarakat yang tertib, aman, dan damai.

\section{B. Pembahasan}

\section{Definisi Internalisasi Nilai}

Internalisasi nilai adalah proses menjadikan nilai sebagai bagian dari diri seseorang. ${ }^{5}$ Lebih lanjut Soedijarto menjelaskan bahwa proses tersebut tercipta dari pendidikan nilai dalam pengertian yang sesungguhnya, yaitu terciptanya suasana, lingkungan dan interaksi belajar mengajar yang memungkinkan terjadinya proses sosialisasi dan internalisasi nilai-nilai. ${ }^{6} \mathrm{Chabib}$ Thoha memaparkan, internalisasi nilai merupakan teknik dalam pendidikan nilai yang sasarannya adalah sampai pada pemilikan nilai yang menyatu dalam kepribadian peserta didik. ${ }^{7}$ Melalui internalisasi nilai kepribadian peserta didik dapat mewujudkan suasana yang terkondisikan dalam proses pembelajaran.

\section{Unsur-unsur Internalisasi Nilai}

Menurut Majid Irsan al-Kailany yang dikutip Maksudin ${ }^{8}$ berkaitan dengan unsur-unsur internalisasi nilai, beliau memaparkan:

a. Nilai keindahan yang berkaitan dengan yang diperoleh melalui karya seni pada umumnya nampak pribadi, misalnya

${ }^{4}$ Sutrisno, Pembaharuan dan Pengembangan Pendidikan Islam, (Yogyakarta, Fadilatama, 2011), hlm. 85.

${ }^{5}$ Soedijarto, Menuju Pendidikan Nasional Yang Relevan Dan Bermutu, (J karta: BalaiPustaka, 2003), Cet. 4, hlm. 14.

${ }^{6}$ Soedijarto, Menuju Pendidikan Nasional..,hlm. 128.

${ }^{7}$ Chabib Thoha, Kapita Selekta Pendidikan Islam, (Yogyakarta: Pustaka Pelajar, 2006), hlm. 87-93.

${ }^{8}$ Maksudin, Pendidikan Nilai Sistem Boarding School di SMP Islam Terpadu Abu Bakar (Yogyakarta: Pps UIN Sunan Kalijaga, 2008), hlm. 52. 
nilai keindahan berpakaian, nilai keindahan bangunan, dan nilai keindahan pameran-pameran yang bermacam-macam.

b. Nilai-nilai instrumental, yaitu nilai yang diperoleh melaui media yang digunakan untuk mencapai tujuan, misalanya nilai susunan percakapan, nilai kemasyarakatan, dan nilainilai akhlak yang bermacam-macam, serta nilai moral, yaitu nilai yang ditentukan berdasarkan tujuan dan perbuatan yang benar.

c. Penyebarluasan nilai yang dapat ditemukan secara kolektif melalui persamaan, pembiasaan, tempat-tempat umum, pergaulan yang baik dan benar sesuai kewajiban warga masyarakat.

\section{Definisi Konsepsional}

Internalisasi nilai merupakan sesuatu yang urgen bagi peserta didik dalam pembelajaran. Melalui internalisasi nilai kepribadian peserta didik dapat mewujudkan suasana yang kondusif dalam proses belajar. Adapun sesuatu yang tidak bernilai akan menimbulkan perasaan negatif seperti tidak senang, marah, benci dan antipati. Lebih lanjut dinyatakan pula bahwa pengamalan dan penghayatan nilai melibatkan hati nurani dan akal budi. Hati menangkap nilai dengan merasakannya dan budi menangkap nilai dengan memahami atau menyadarinya. Sehingga nilai yang ada pada diri setiap individu menurut penulis merupakan sesuatu yang harus dikembangkan karena batasan nilai setiap manusia berbeda.

\section{Tahapan Internalisasi Nilai}

Penelitian ini merupakan penelitian kualitatif deskriptif dengan metode dalam memperoleh data melalui observasi, wawancara dan dokumentasi. Dalam analisis data dengan menggunakan reduksi data, karena pendekatan yang digunakan adalah kualitatif, bertujuan untuk mendeskripsikan Internalisasi Nilai-Nilai Akblaqul Karimabdalam hal inisiswa Kelas V pada 
Pembelajaran Akidah Akhlaq di Madrasah Ibtidaiyah Kecamatan Windusari kabupaten Magelang studi kasus di MI Al-Islam Balesari, MI Al-Islam Kembangkuning, dan MI Nurul Huda Candisari. penelitian ini merupakan penelitian lapangan.

Mengenai tahapan internalisasi nilai ini, Soedijarto menyatakan bahwa bila nilai yang akan ditanamkan dimaksudkan untuk sepenuhnya menjadi bagian sistem kepribadian setiap anak didik, maka tahap pengenalan dan pemahaman, penerimaan dan pengintegrasian, ketiga-tiganya wajib ditempuh. Sedangkan tiga tahap tersebut merupakan teori yang dikemukakan oleh Krathwhol dan telah dikerucutkan oleh Soedijarto. ${ }^{9}$ Dalam hal ini dapat dipaparkan sebagai berikut:

\section{a. Tahap Pengenalan dan Pemahaman}

Berdasarkan data yang tersedia atau terkumpul, dalam tahap pengenalan dan pemahaman, yaitu bagaimana peserta didik mulai tertarik memahami dan menghargai pentingnya nilai-nilai akblaqul karimah bagi dirinya terwujud dalam pertemuan dikelas atau pertemuan dalam jam belajar. Kelebihan-kelebihan dan kekurangan-kekurangan tahap pengenalan dan pemahaman ini adalah sebagai berikut:

Adapun Kelebihan-kelebihannya:

1.) Adanya penambahan jam mata pelajaran dengan materi tersendiri sehingga memberikan nilai tambah dalam tahapan pengenalan dan pemahaman ini.

2) Mata pelajaran aplikasi agama tersebut tidak dimasukkan dalam ujian sekolah sehingga membuka banyak kesempatan untuk penekanan pada aspek afektif siswa.

3) Materi-materi yang disampaikan dalam bidang studi aplikasi agama telahterdapat dalam mata pelajaran-mata pelajaran agama terutama Siswa Kelas V di MI Al-Islam Balesari, MI Al-Islam Kembangkuning, dan MI Nurul Hudasehingga

9 Soedijarto, Menuju Pendidikan Nasional Yang Relevan Dan Be mutu, (Jakarta: Balai Pustaka, 2003) hlm. 149. 
terjadi pengulangan pembelajaran yang dapat memperkuat ingatansiswa.

Adapun yang menjadi kekurangan-kekurangannya adalah:

1) Metode belajar mengajar yang digunakan masih bersifat sederhana, yaknitidak memiliki perbedaan yang berarti dengan metode-metode pembelajarandi sekolah-sekolah lain.

2) Materi yang sudah diajarkan dalam pelajaran agama lain, selain memiliki sisipositif juga memiliki sisi negatif, yaitu memakan waktu lebih banyak.

\section{b. Tahap Penerimaan}

Agar suatu nilai dapat diterima, diperlukan suatu pendekatan belajar yang merupakan proses sosial, yaitu pendekatan yang memungkinkan pelajar merasakan diri dalam konteks hubungannya dengan lingkungan, bukan suatu proses yang menempatkan pelajar dalam suatu jarak dengan yang sedang dipelajari. MI Al-Islam Balesari, MI Al-Islam Kembangkuning, dan MI Nurul Huda memiliki banyak sarana. Sarana-sarana tersebut memiliki nilai penting dalam tahap penerimaan ini. Hal-hal yang menjadisarana dalam proses internalisasi nilai-nilai akblaqul karimabkhususnya tahappenerimaan ini kegiatan keagamaan, tata tertib (baik tata tertibguru, karyawan dan siswa), lingkungan benda, peneladanan, pembiasaan sertadorongan-dorongan atau pemberian motivasi melalui pemberian penghargaandan pujian terhadap siswa untuk mengamalkan nilai-nilai akblaqul karimah yangtelah dipahami dan mulai diterima.

Adapun kelebihan dan kekuranganpadatahap penerimaan ini adalah sebagaiberikut:

1) Kelebihan:

Terdapat banyak kegiatan-kegiatan keagamaan.

Tata tertib, keteladanan, pembiasaan dan suasana lingkungan secara bersama-sama telah mengarah pada terwujudnmya 
proses internalisasinilai-nilai akhlaqul karimah oleh peserta didik.

2) Kekurangan:

a) Tidak adanya kejelasan tahapan untuk nilai-nilai akhlak tertentu. Ketikatahap pertama telah dilalui belum dapat ditentukan kapan tahap keduayakni tahap penerimaan akan dilalui pula oleh peserta didik. Bisa jadiketika guru menyampaikan materi tentang istiqomah, siswa telabmenyaksikan sebelumnya sang guru tersebut mengamalkan sikapistiqomah sejak awal sebelum pengajaran materi tersebut.

b) Tidak adanya kewajiban bagi seluruh siswa untuk mengikuti semua kegiatan keagamaan (mengingat banyaknya jumlah siswa) khususnya yang bersifat Islami, mempengaruhi terhadap optimalnya internalisasi nilainilai akhlaqul karimah pada tahap penerimaan.

\section{c. Tahap Pengintegrasian}

Pada tahap ini seorang pelajar mulai memasukkan nilai kedalam keseluruhan sistem nilai yang dianutnya.Tahap pengintegrasian ini merupakan hasil dari tahap-tahap sebelumnya, jadi tahap ini ditentukan oleh tahap pengenalan dan pemahaman dan tahap penerimaan.

Beberapa model strategi pendidikan nilai, strategi yang digunakan dalam internalisasi nilai-nilai akhlaqul karimab kelas siswa kelas V di MI Al-Islam Balesari, MI Al-Islam Kembangkuning, dan MI Nurul HudaKecamatan Windusari Kabupaten Magelang adalah strategi transinternal. Guru yang mempraktikkan strategi transinternal berarti telah melaksanakan tugas, peran dan tanggungjawab sebagai konservator (pemelihara) transmitor (penerus) dan transformator (penterjemah) sistem nilai melalui penjelmaan dalam pribadi dan prilakunya melalui proses interaksinya dengan peserta didik serta sebagai organisator (penyelenggara) terciptanya proses edukatif yang dapat dipertanggungjawabkan baik secara formal (kepada pihak yang mengangkat dan menugaskannya) 
maupun secara formal (kepada sasaran didik serta Tuhan yang menciptakannya). ${ }^{10}$ Sehingga tujuan menjadikan para peserta didik untuk mempunyai akhlaqul karimah dapat terwujud.

\section{d. Pendekatan dalam internalisasi nilai-nilai akhlaqul karimah}

Internalisasi nilai-nilai akhlaqul karimah pada pembelajaran Akidah Akhlaqsiswa kelas V di MI Al-Islam Balesari, MI Al-Islam Kembangkuning, dan MI Nurul HudaKecamatan Windusari Kabupaten Magelang menggunakan pendekatan penghayatan. Dalam pendekatan penghayatan ini nilai-nilai akblaqul karimah dikembangkan dengan jalan melibatkan siswa dalam kegiatan empirik yang disertai dengan keterlibatan aspek afektifnya.Demi terwujudnya pendekatan tersebut, banyak diadakan kegiatankegiatan yang melibatkan siswa secara langsung.Kegiatan tersebut ada yang bersifat wajib diikuti bagi seluruh siswa seperti membaca asma'ul busna setiap hari pada saat awal jam belajar atau jumat bersih.

Disamping itu terdapat juga penugasan-penugasan dari pendidik terhadap siswa untuk meneliti fenomena-fenomena dilingkungan masyarakat sekitar masing-masing siswa kaitannya dengan nilai-nilai akhlaqul karimah, adanya contoh-contoh yang bisa menjadi teladan serta situasi lingkungan.

Selain menggunakan pendekatan penghayatan di kelas $\mathrm{V}$ di MI Al-Islam Balesari, MI Al-Islam Kembangkuning, dan MI Nurul HudaKecamatan Windusaridigunakan juga pendekatan rasional, pendekatan efektif dan kharismatik. Dalam pendekatan rasional, materi nilai-nilai akhlaqul karimah disampaikan secara rasional.Ketika menyampaikan suatu nilai baik atau buruk disertakan pula alasan kenapa sesuatu tersebut dikatakan baik atau buruk, akibat-akibat yang ditimbulkannya, serta dalil-dalilnya dalam agama.Jadi siswa tidak dipaksa untuk menerima suatu nilai

${ }^{10}$ Abin Syamsuddin Makmun, Psikologi Kependidikan, (Bandung: Remaja Rosdakarya, 2002), hlm. 23. 
baik atau buruk tanpa mengetahui alasan-alasannya, runtutannya, akibat dan manfaatnya serta dasar-dasarnya dalam Islam.

\section{e. Metode internalisasi nilai-nilai akhlaqul karimah}

Sebagaimana dengan strategi dan pendekatan diatas, metode yangdigunakan dalam internalisasi nilai-nilai akblaqul karimah siswa inipun memiliki kelebihan-kelebihan dan kekurangan-kekurangan.Adapun kelebihannya sebagai berikut:

1) Sebagai metode yang didalamnya digunakan metode deduktif dan induktif akan dapat menutupi kekurangan dari penggunaan metode deduktif yang kadang-kadang mengabaikan unsur empirik dan dapat menutupi kekurangan dari penggunaan metode induktif yang terlalu berorientasi pada hal-hal yang empirik.

2) Adanya pengembangan mata pelajaran umum, pengembangan keterampilan dan banyaknya kegiatan keagamaan menyediakan banyak waktu dan biaya untuk penerapan metode reflektif ini, baik pada metode deduktifnya maupun induktifnya.

Sedangkan kekurangan-kekurangan dari penggunaan metode tersebut sebagai berikut:

Pengalaman serta lingkungan siswa yang berbeda-beda akan memberikanhasil yang berbeda pula terhadap penerapan metode tersebut, baik padametode deduktif maupun induktif. Ketika suatu nilai tertentu diajarkan bagi siswa yang telah memiliki pengalaman atau pengetahuan maka akansegera dapat mempelajarinya, sedangkan yang tidak akan sulit untukmelakukan abstraksi.

\section{f. Faktor Pendukung}

Adapun yang menjadi faktor pendukung dalam internalisasi nilai-nilai akblaqul karimah siswa kelas V pada pembelajaran Akidah Akhlaqdi MI Al-Islam Balesari, MI Al-Islam Kembangkuning, dan MI Nurul HudaKecamatan Windusari antara lain: 
1) Adanya penambahan jam mata pelajaran pada kegiatan keagamaan dengan materi tersendiri.

2) Berada di lingkungan pedesaan sehingga sangat strategis untuk proses belajar.

3) Kegiatan-kegiatan keagamaan, tata tertib, situasi lingkungan sekolah,keteladanan dan pembiasaan secara bersama-sama telah mengarah.

4) Rata-rata orang tua wali siswa adalah petani agraris sehingga sikapkesederhanaan lebih mewarnai keberadaan siswa.

5) Disiplin ilmu yang dikembangkan, pembekalan skill, kegiatan-kegiatan keagamaan, tata tertib, situasi lingkungan sekolah, keteladanan danpembiasaan semuanya memiliki posisi yang potensial terhadapmaksimalnya penggunaan strategi, pendekatan dan metode yang digunakan dalam internalisasi nilai-nilai akblaqul karimah.

\section{g. Faktor Penghambat}

Adapun yang menjadi faktor penghambat dalam internalisasi nilai-nilai akblaqul karimah siswa kelas $\mathrm{V}$ pada pembelajaran Akidah Akhlaqdi MI Al-Islam Balesari, MI Al-Islam Kembangkuning, dan MI Nurul HudaKecamatan Windusari antara lain adalah:

1) Tingkat pemahaman keagaaman masing-masing individu para siswa menjadikan proses internalisasi nilai-nilai akblaqul karimah menjadi beraneka ragam.

2) MI Al-Islam Balesari, MI Al-Islam Kembangkuning, dan MI Nurul HudaKecamatan Windusariberada di yayasan swasta sehingga sarana dan prasarana dalam pembelajaran akhlaq kurang maksimal.

3) Tidak semua dewan guru dan pegawai memiliki perhatian yang serius dalamhal internalisasi nilai-nilai akblaqul karimah. 


\section{Simpulan}

Nilai-nilai akhlaqul karimah yang ditanamkan kepada peserta didik kelas $\mathrm{V}$ di MI Al-Islam Balesari, MI AlIslam Kembangkuning, dan MI Nurul HudaKecamatan Windusarisetelah memperoleh pembelajaran Akidah Akhlaq meliputi aspek keimanan, ihsan, takwa, ikhlas tawakal, syukur melalui pembelajaran di kelas. Selain itu juga dilakukan beberapa kegiatan kegamaan yang di tanamkan, seperti Peringatan Hari Besar Islam (PHBI), peringatan maulid Nabi, kebiasaan sholat dluba dan sholat dluhur berjamaah.

Implementasi internalisasiakblaqul karimah dalam pembelajaran Akidah Akhlaq di MI Al-Islam Balesari, MI Al-Islam Kembangkuning, dan MI Nurul HudaKecamatan Windusarimelalui beberapa tahapan meliputi:

a. Tahapan pengenalan dan pemahaman yaitu bagaimana peserta didik mulai tertarik memahami dan menghargai pentingnya nilai-nilai akhlaqul karimah bagi dirinya terwujud dalam pertemuan dikelas atau pertemuan dalam jam belajar.

b. Tahapan penerimaan seperti Hal-hal yang menjadisarana dalam proses internalisasi nilai-nilai akblaqul karimabkhususnya tahappenerimaan ini kegiatan keagamaan, tata tertib (baik tata tertibguru, karyawan dan siswa), lingkungan benda, peneladanan, pembiasaan sertadorongan-dorongan atau pemberian motivasi melalui pemberian penghargaandan pujian terhadap siswa untuk mengamalkan nilai-nilai akblaqul karimah yangtelah dipahami dan mulai diterima.

c. Tahapan pengintegrasian, yaitu pada tahap ini seorang pelajar mulai memasukkan nilai kedalam keseluruhan sistem nilai yang dianutnya. 


\section{Daftar Pustaka}

Makmun, Abin Syamsuddin, Psikologi Kependidikan, Bandung: Remaja Rosdakarya, 2002.

Maksudin, Pendidikan Nilai Sistem Boarding School di SMP Islam Terpadu Abu BakarYogyakarta: Pps UIN Sunan Kalijaga, 2008.

Mulyana, Rahmat, Mengartikulasikan Pendidikan Nilai, Bandung: Alfabeta, 2004.

Saleh, Khoirul dan Ahmad Munif, "Membangun Karakter Budaya Politik Dalam Berdemokrasi" dalam Jurnal Addin Volume 9, Nomor 2, Agustus 2015.

Soedijarto, Menuju Pendidikan Nasional Yang Relevan Dan Bermutu, Jakarta: Balai Pustaka, 2003.

Soedijarto, Menuju Pendidikan Nasional Yang Relevan Dan Bermutu, Jakarta: Balai Pustaka, 2003.

Sutrisno, 2011. Pembaharuan dan Pengembangan Pendidikan Islam, Yogyakarta, Fadilatama.

Thoha, Chabib, Kapita Selekta Pendidikan Islam, Yogyakarta: Pustaka Pelajar, 2006.

Zaenul Fitri, Agus, Pendidikan Karakter Berbasis Nilai dan Etika di Sekolah, Yogyakarta: Ar-Ruzz Media, 2012.

Zuhari, Metodik Khusus Pendidikan Agama; Dilengkapi dengan Sistem Modul dan Permaianan Simulasi, Surabaya: Biro Ilmiah Fakultas Tarbiyah IAIN Sunan Ampel Surabaya dan Usaha Offset Printing, 1983. 